\title{
Can we stop malaria parasites in the skin?
}

\author{
Ross Douglas, Miriam Ester, Janina Hellmann, Friedrich Frischknecht ${ }^{*}$ \\ From Challanges in malaria research: Core science and innovation \\ Oxford, UK. 22-24 September 2014
}

\section{Background}

Since the discovery of malaria transmission by mosquitoes, it was assumed that the parasites are injected directly into the blood stream. However, indirect experiments [1] and direct microscopic observations using mice as hosts and fluorescent rodent malaria species showed that the parasites are instead injected into the skin. These Plasmodium sporozoites then migrate rapidly through the dermis and enter blood or lymph vessels [2]. Stopping sporozoite motility also halts infection [3]. We aim at understanding the mechanisms that drive sporozoite motility and identify drug-like compounds that stop parasite locomotion. To this end, we have adapted and developed new methods including a screening pipeline to test small molecules that could interfere with motility and thus stop Plasmodium transmission at the skin stage $[4,5]$.

\section{Materials and methods}

A screening pipeline was developed that allowed mediumthroughput assessment of small molecules as possible inhibitors of sporozoite motility in vitro. This was followed by in vivo testing during transmission from mosquito to mouse.

\section{Results}

We tested over 200 compounds selected from a library of drugs approved by the Federal Drug Administration for their potential to interfere with motility. We identified two molecules that inhibited in vitro motility in the nano-molar range. When these two compounds were tested during the transmission by mosquitoes, an ectopically applied drug resulted in a decrease of transmission efficiency while an orally given drug showed no effect on transmission at non-toxic doses.

Published: 22 September 2014

$$
\text { Centre for Infectious Diseases, Heidelberg University, Heidelberg 69120, }
$$$$
\text { Germany }
$$$$
\text { C Biomed Central }
$$

(C) 2014 Douglas et al; licensee BioMed Central Ltd. This is an Open Access article distributed under the terms of the Creative Commons Attribution License (http://creativecommons.org/licenses/by/4.0), which permits unrestricted use, distribution, and reproduction in any medium, provided the original work is properly cited. The Creative Commons Public Domain Dedication waiver (http:// creativecommons.org/publicdomain/zero/1.0/) applies to the data made available in this article, unless otherwise stated.

\section{References}

1. Sidjanski SP, Vanderberg JP: Delayed migration of Plasmodium sporozoites from the mosquito bite site to the blood. Am J Trop Med Hyg 1997, 57:426-429.

2. Amino R, Thiberge S, Martin B, Celli S, Shorte S, Frischknecht F, Ménard R: Quantitative imaging of Plasmodium transmission from mosquito to mammal. Nat Med 2006, 12:220-224.

3. Kebaier C, Voza T, Vanderberg J: Kinetics of mosquito-injected Plasmodium sporozoites in mice: fewer sporozoites are injected into sporozoite-immunized mice. PLoS Pathog 2009, 5:e1000399.

4. Hegge S, Kudryashev M, Smith A, Frischknecht F: Automated classification of Plasmodium sporozoite movement patterns reveals a shift towards productive motility during salivary gland infection. Biotechnol J 2009, 4:903-913

5. Hegge S, Münter S, Steinbüchel M, Heiss K, Engel U, Matuschewski K, Frischknecht F: Multistep adhesion of Plasmodium sporozoites. FASEB J 2010, 24:2222-2234.

doi:10.1186/1475-2875-13-S1-O7

Cite this article as: Douglas et al:: Can we stop malaria parasites in the skin? Malaria Journal 2014 13(Suppl 1):07. and take full advantage of:

- Convenient online submission

- Thorough peer review

- No space constraints or color figure charges

- Immediate publication on acceptance

- Inclusion in PubMed, CAS, Scopus and Google Scholar

- Research which is freely available for redistribution 